\title{
Britain and Ottoman Domestic Politics: From the Young Turk Revolution to the Counter-Revolution, 1908-9
}

\section{Hasan Ünal}

To cite this article: Hasan Ünal (2001) Britain and Ottoman Domestic Politics: From the Young Turk Revolution to the Counter-Revolution, 1908-9, Middle Eastern Studies, 37:2, 1-22, DOI: $10.1080 / 714004391$

To link to this article: https://doi.org/10.1080/714004391

曲 Published online: 08 Sep 2010.

Submit your article to this journal $₫$

Џلll Article views: 169 


\title{
Britain and Ottoman Domestic Politics: From the Young Turk Revolution to the Counter-Revolution, 1908-9
}

\author{
HASAN ÜNAL
}

The counter-revolution, or the Incident of the 31 March 1909 against the Committee of Union and Progress (hereafter the CUP) (the Young Turks as they are known in Western historiography) is one of the most controversial points in Anglo-Turkish relations in the period under review. It has been suggested that the counter-revolution constituted a watershed in Britain's relations with Turkey marking the end of the honeymoon, which the two countries had enjoyed following the Young Turk revolution of July 1908. ${ }^{1}$ It is maintained that this was due primarily to unlimited British support for the 'Liberal Unions' (Ahrar) which had become erstwhile adversaries of the CUP since the restoration of the Constitution. The British Embassy particularly was suspected of having been involved in fomenting, through various channels, even perhaps of funding and organizing the counterrevolution against the CUP. ${ }^{2}$ According to these accounts, Britain's earlier commitments to Russia under the Anglo-Russian convention of 1907 determined London's policies towards the Ottoman Empire. And Britain sided with those least likely to obtain the upper hand because of her sneaking desire to give up Turkey as a prospective future ally by backing the wrong horse and thus antagonizing the CUP which was more likely than not to emerge victorious from the power struggle. ${ }^{3}$

Before looking into the role that Britain allegedly played, it is first necessary to take a glance at her attitude towards differences of opinion within various Young Turk groups and between them and the Cabinet, for example, the CUP, the Liberal Unions and Kamil Pasha. From the outset, Britain's attitude towards differences of opinion between them all can be interpreted as one of indifference.

Soon after his arrival in Constantinople, the British Ambassador, Sir Gerald Lowther, detected that there was a lack of experienced leading figures among the Young Turks, a view that was to be confirmed by Fitzmaurice, Chief Dragoman of the Embassy ${ }^{4}$ and later in the autumn by 
Sir Valentine Chirol, The Times editor. ${ }^{5}$ Nevertheless, the Ambassador admitted that 'things have gone as well as they could' ${ }^{6}$ despite the fact that the CUP was just 'a collection of good-intentioned children'. ' Yet, he was not over optimistic. He feared that one section within the CUP who had no confidence in the Sultan 'even with his wings so clipped' might attempt to dethrone him. This, he thought, coupled with the sacking of many other officials and officers would lead to untoward incidents, making even the return of the old regime possible. He, therefore, endeavoured to 'temper the zeal of the reformers' and pinned all his hopes on what he called 'the moderation of the large majority of the Committee' to prevent a disaster. ${ }^{8}$

Lowther's meeting with the two prominent CUP figures Mehmed Talat (later Talat Pasha) and Bahaeddin Şakir (an influential member of the inner circle of the CUP) relieved him of the anxiety that the Young Turks would mess things up by 'going too fast' in their endeavour to reform the country. Much to Lowther's satisfaction the two leaders utterly repudiated the rumour that the CUP was anxious to depose the Sultan. If anything, they emphasized the vital importance of keeping the Sultan on the throne and expressed their satisfaction with Kamil Pasha's cabinet. ${ }^{9}$

However, this rosy picture was not to last for long. His meeting with Ahmed Riza, a Young Turk leader who had long been in exile in France before the revolution, cold-watered his enthusiasm. The latter, while admitting that he knew nothing about the details of the financial arrangements and loans, suggested that the British Government now come forward and offer Turkey spontaneously some millions rather than content herself with encouraging financiers and bankers in return for a guarantee to ratify it by the Turkish Parliament when it met. The Ambassador replied that Britain had also a Parliament, which would be most unlikely to sanction such a transaction. Ahmed Riza's second remark that Britain, seeing that genuine steps were being taken in the direction of reforms, should now extend her protection, in accordance with the Cyprus Convention of 1878, to the whole Empire did seem to the Ambassador to be a premature question to raise. Ahmed Riza, 'too loquacious with immature views', what is more, seeming to favour a more radical programme, altogether made a very poor impression on Lowther. In the Foreign Office, Mallet, Head of the Eastern Department, found it disappointing; but still hoped that it did not represent the 'Young Turk intelligence', while Sir Charles Hardinge, Permanent Under-Secretary in the Foreign Office dismissed it as 'worthless'. ${ }^{10}$

British Foreign Secretary, Sir Edward Grey and Hardinge, it so happened, had an opportunity of meeting Ahmed Riza together with another leading CUP figure, Dr Nazım, in London at the height of the Bosnian crisis in mid-November, 1908. ${ }^{11}$ The two leaders used this occasion to express their indignation at the idea of the recognition of the annexation in return for 
some pecuniary compensation which would, they argued, be tantamount to selling their rights for money. Instead, they proposed that the annexed provinces be transformed into a buffer state under Austro-Hungarian administration. The only means they suggested to achieve this end was that Britain, France and hopefully Russia should associate themselves with the Turkish protest against the Austro-Hungarian action for at least five or six months by which time Turkey would most likely have made an entente with the Balkan States. Such a strong combination would then compel Austria to give way. But at the same time, they laid much stress on the point that Bulgaria should only be allowed to remain in civil possession of Eastern Rumelia, depriving her of any right to use the region militarily. ${ }^{12}$ As this was bound to push Bulgaria into the Austro-Hungarian orbit, Grey and Hardinge told them that any combination between Turkey, Serbia and Montenegro would be of little use against an Austro-Bulgarian front. In addition, no such condition as they suggested could ever be imposed upon Bulgaria without a war. Moreover, a simple protest, even if made and insisted upon by all the Powers in question for some five or six months, would not advance matters.

Their offer of alliance to Britain was politely turned down. Grey pointed out to them that Britain's policy was based on the principle of keeping 'our hands free, though we made ententes and friendship'. For instance, the entente with Japan was limited to certain distant questions in the Far East. But, Grey made it quite clear that the British sympathy was entirely with the Young Turks, and that the Foreign Office was prepared to supply Turkey, if desired, with the necessary 'know-how' and experts to organize Customs, Police and so forth. The impression that the CUP leaders left with Grey and Hardinge was most disappointing. Ahmed Riza in particular seemed to be quite 'impractical', something of an idealist, at least as far as dealing with this external crisis was concerned. Grey was sure that 'the Turkish Government will have a difficult job if all the Young Turks are like them' ${ }^{13}$ Hardinge had never met 'visionaries ... with scantly political ideas' like them before. ${ }^{14}$

In the meantime, Lowther came to notice the interwoven relations between the CUP and the army, and was inclined to the view that "possibly all this may end in a military dictatorship' ${ }^{15} \mathrm{He}$ also noticed that the CUP was going too fast in preaching secular tenets amongst the masses, and feared that it would, if carried on in the same manner, cause 'disturbances' ${ }^{16}$ His anxiety as to the internal situation gathered momentum when he heard a rumour that the CUP would soon dethrone the Sultan. In fact, this was probably the only point upon which all the factions within the CUP agreed. Yet, Lowther could not simply see how a deposition would address the situation, given that there was still 'a sad lack of men and money to deal with the complications of an entirely new system'. ${ }^{17}$

It must be borne in mind that the alarm felt by the Embassy and the 
Foreign Office at the idea was in no way because of the 'beaux yeux' of the Sultan. On the contrary, Grey opposed a royal visit to Constantinople, on the grounds that it was to be to the present Sultan; whereas he would have supported a visit by the King to 'a Young Turk government' as it 'would have a beneficial effect upon our Mohammedan subjects everywhere'. ${ }^{18}$ Initially, there had perhaps been some confusion as to the line to be taken as regards the deposition. For instance, Grey minuted on Lowther's dispatch, reporting his advice to Mehmed Talat and Bahaeddin Şakir not to attempt at dethronement: 'we need not lay too much stress upon deference to the present Sultan'. ${ }^{19}$ One thing was, however, clear: both the Foreign Office and the Embassy were fearful of the widespread disturbances any such attempt would lead to.

Lowther's already shaken confidence in the CUP was to further suffer. In mid-December, two bribery cases involving people from the inner circle of the CUP with English businessmen were brought to his notice. ${ }^{20}$ Despite the fact that the English competitors were given the contract as the result of the bribery, Lowther was disgusted with the whole affair, but could not bring the matter before the Grand Vizier. If he did, he would have to give chapter and verse, exposing British competitors and ruining their future chances. Despite all this, he was not still prepared to put the whole blame on the CUP, as it was, after all, a secret society. However, the pace of events was certainly making him 'sick of the Committee', and he hoped that it would come into the open. ${ }^{21}$

It must not be inferred, however, as is often the case in Turkish historiography, that the British liked Kamil Pasha any better. ${ }^{22}$ His conduct of affairs at the outset of the Bosnian crisis was seen as intransigent, obstructive and impracticable. More particularly, his attitude towards an alliance with the Balkan States, his persistent refusal to consider an entente with Bulgaria was far from satisfactory. He was seen as negotiating with Serbia, Montenegro and even Austria-Hungary with no regard to British advice. So much so, when he asked Lowther views of the British government in connection with a secret agreement proposed by AustriaHungary, the Foreign Office officials concerned gave free rein to their feelings. Kamil Pasha was soliciting reaction to a proposal that the Dual Monarchy give an undertaking not to enter into any commitment contrary to the integrity of the Ottoman Empire, and recognize Sanjak as an integral part of Turkey in return for the withdrawal of the Turkish protest to the annexation of Bosnia-Herzegovina by the Dual Monarchy. The minutes on Lowther's dispatch read: 'while Turkey is negotiating with a variety of governments, it is somewhat difficult for us to assist her'. Tilley, a Foreign Office official in the Eastern Department reminded that 
Kamil Pasha is a very cunning old gentleman, whose methods are very oriental. When he took refuge at the Consulate General, he was, I believe, in no sort of danger and merely wished to manoeuvre himself back to Constantinople and become Grand Vizier ... ${ }^{23}$

Lowther described his scheme in connection with the transformation of the annexed provinces into an autonomous buffer state, and his negotiations for a defensive and offensive alliance with Serbia and Montenegro as 'rather of a wild order'. The Grand Vizier was, Lowther described, a 'frightfully difficult man to get to talk and so frightfully indistinct ... that it is very difficult to appreciate what really is in his mind' ${ }^{24}$ Hardinge in the Foreign Office was no less annoyed with the Grand Vizier's negotiations in Constantinople with 'those rotten countries', Serbia and Montenegro. ${ }^{25}$

The continual power struggle between the Young Turks and Kamil Pasha, deepening and getting out of control, and later on, involving the Liberal Unions and 'reactionary' forces against the CUP created an atmosphere in which the British had to adopt a cautious line of policy.

The differences of opinion between the CUP and Kamil Pasha came to a head in December. The British displayed a striking example of caution. Some members of the Balkan Committee of the House of Commons, Noel Buxton MP and his friends, who had been visiting Constantinople were invited by a small section of the CUP to an entertainment in the Grand Vizier's house without the latter's express consent. Kamil Pasha, furious with what he called 'the dictation of the CUP' refused to allow them into the house, as it was not, in his own words, 'the Committee restaurant'. ${ }^{26}$ Mallet deprecated the friction caused by the Balkan Committee between the CUP and Kamil Pasha, ${ }^{27}$ while Grey instructed Lowther to warn Buxton to abstain from mixing up in any differences between any section of the Young Turks and the Grand Vizier' ${ }^{28}$ Lowther, though finding it beyond his power to intervene, was particularly relieved when they left. ${ }^{29}$ Given that the Foreign Office was quite aware of the "woeful effect" that the King's congratulatory message to the Sultan which included a reference to the appointment of Kamil Pasha as Grand Vizier had produced, ${ }^{30}$ this prudent attitude could have been predicted.

One gathers from primary sources in British archives that Kamil Pasha, though never regarded as more than the 'least worst' alternative, ${ }^{31}$ gradually emerged from the cloudy internal situation as wiser than other contesters towards the end of the year. Yet, this did not mean active British involvement in backing him against the CUP. On the contrary, Lowther assured the CUP on several occasions that Britain was by no means relying upon Kamil Pasha. ${ }^{32}$ In fact, the British postponed, for this reason, conferring upon him a GCB. ${ }^{33}$ With the internal situation showing no signs of improvement, Lowther was now sure that a fight between the CUP and 
the government headed by Kamil Pasha was unavoidable. He hoped that the Government would win the day, ${ }^{34}$ a view shared by the Foreign Office. ${ }^{35}$

Although Lowther's hopes that Kamil would get a vote of confidence in the Parliament and establish himself firmly in the saddle ${ }^{36}$ came true in January, they were to be proven short-lived. The manner in which the Grand Vizier attempted to get rid of the Ministers of War and Marine, ${ }^{37}$ whom he accused of being hand in glove with the CUP, brought about his downfall just a month later. ${ }^{38}$ Despite the assurances from the new Grand Vizier, Hüseyin Hilmi Pasha, former Inspector General of Macedonia under Sultan Abdülhamid that he would adhere to Kamil Pasha's foreign policy, Lowther was sure that the new government was bound to 'do the bidding of the Committee' ${ }^{39}$ This would, according to the Ambassador, make the Cretan question more and more acute as the CUP represented 'purely Turkish versus Ottoman interests'. All in all, the daily worsening internal situation coupled with gloomy international political atmosphere was filling Lowther with despair ${ }^{40}$ Hardinge predicted rightly that 'it all seems to be gradually tending to a military despotism of a nationalist and chauvinistic character ...', ${ }^{41}$ whereas Grey pinned all his hopes on the ability and statesmanship of Rifat Pasha, the newly appointed Foreign Minister, who had been Ottoman Ambassador in London. ${ }^{42}$

However, this was not enough to lessen the fears of the Ambassador who saw little prospect of improvement in internal politics. Added to continued rumours of a plot to get rid of the Sultan, ${ }^{43}$ the CUP's interference with governmental affairs rendered the whole cabinet powerless ${ }^{44} \mathrm{He}$ then decided to display a 'cold' attitude to the CUP in the hope that it might influence it. ${ }^{45}$ Yet, he still endeavoured to be on good terms with what he called some 'good men amongst them' ${ }^{46}$

Until the counter-revolution, on 13 April 1909, Lowther's pessimistic reports continued to pile up in the Foreign Office. ${ }^{47}$ But it must be remembered that this criticism of the CUP was kept to private correspondence because the Embassy took great care not to get dragged into the row between the CUP and the combined opposition, which was growing by leaps and bounds. Given that the internal situation on the eve of the counter-revolution was tense and hopeless, Lowther's despair does not seem to be ill founded.

All evidence confirms that the Embassy had no foreknowledge of the coming revolution. Apart from some guesses made by Lowther and the Embassy staff consequent on widespread insubordination and growing discontent among troops due to the preaching of anti religious, secular tenets, ${ }^{48}$ it is safe to say that the Embassy was caught napping. 
In his first telegram on 13 April, Lowther informed the Foreign Office of the 'mutiny', supported by a large number of 'softas', and not directed at the Constitution but 'rather at the CUP', though the application of the Sharia Law was demanded. ${ }^{49}$ In the next dispatch, Lowther reported the resignation of the whole cabinet and the appointment of Kamil and Nazım Pashas as Grand Vizier and the Minister of War respectively together with Said Pasha as the Minister for Foreign Affairs. Hardinge, cheered up with the news a little, thought that 'if Kamil returns to power, all may yet be well', whereas Mallet reminded him that, according to the 'Times', the Sultan had not called for Kamil, but selected Tevfik. ${ }^{50}$

The following day, Lowther called Tevfik Pasha's Cabinet 'colourless', and asked for some men-of-war to be held in readiness to proceed to Beirut, Smyrna and Salonica in order to protect British interests, as, unless the mutiny were to be promptly suppressed, it might lead to further disturbances in the provinces. ${ }^{51}$ The Foreign Office, still at a loss to grasp the real significance of what was taking place, indulged in guesswork. Mallet thought that the Sultan had presumably benefited 'by the quarrel between the Union Liberals and the Committee of Union and Progress to appoint a cypher and govern himself', whereas another official expressed reservations about the Sultan's alleged regain of control. It was obvious that the Foreign Office found itself very much in the dark; as Hardinge remarked, much more than Lowther had reported was already in The Times. ${ }^{52}$

Although Lowther noticed that this was a 'distinct defeat of the CUP, ${ }^{53}$ and their ultra-liberal ideas, for which the country is not ripe' ${ }^{54}$ he appeared quite confused and apprehensive;

One must regard the situation as surrounded with the greatest possible danger ... The Hodjas and Softa class united with the men of different regiments are not likely to show much reason ... it is all very bad and one must look in the future for a violently chauvinistic attitude ...55

The Military Attaché was no less apprehensive. He found it 'deplorable in every respect that it should be possible for a few mutinous battalions in the Capital to upset the whole government of the country at a moment when Turkey has every reason for desiring to present an appearance of stability as well as continuity of policy'.56

On 15 April, with the appointment of Nazım Pasha to the command of the Constantinople garrison the situation would, Lowther hoped, improve. Rifat Pasha, who retained his office, ${ }^{57}$ expressed a wish to Lowther that Britain would not hesitate to give diplomatic support to the new government, which was totally resolved to stick to the Constitution together with the Sultan. ${ }^{58}$ The Foreign Office's reply strikingly underlines the policy that Britain had been pursuing since the Young Turk revolution. That said, Britain 
was prepared to support any government in Turkey as long as it endeavoured to safeguard public interests and secure a development in administration. But no specific promise of support for the new government was made..$^{9}$

What was Lowther doing at Constantinople at this stage? He first ascertained of the Consul General at Salonica, Harry Lamb, as to the likelihood of the IIIrd Army, stationed in Salonica, marching on Constantinople. ${ }^{60}$ Lamb informed the Ambassador that the officers of the IIIrd Army were determined to reverse the verdict of the coup in Constantinople, and that they had been assured of the support of the IVth Army at Adrianople. ${ }^{61}$

In his report to the Foreign Office on 16 April, Lowther played down the threats from the IIIrd Army headquarters as their original plan to join Mahmud Muhtar Pasha, former Commander of the Constantinople Garrison, had fallen through as a result of the latter's escape from the Capital. ${ }^{62}$ This dispatch caused some alarm at the Foreign Office that Bulgaria would move in Macedonia in the event of a clash between rival army units. As it was admittedly beyond the power of the Foreign Office to stop Bulgaria, Grey merely hoped that the position of the government, strengthened by the appointment of Nazım Pasha, would perhaps prevent such a clash. ${ }^{63}$

At this juncture, Lowther was, evidently, being misinformed from Adrianople and Üsküb (Skopje). The reason why Lowther played down the threats from the IIIrd Army was his disbelief in the IVth Army stationed at Adrianople joining the former. This was due to the telegrams he received from the Consular Officer at Adrianople casting doubts on such likelihood. ${ }^{64}$ Information from Consul Satow at Üsküb was of a similar nature. The commander of the Vth division at Üsküb was, according to the Consul, very reluctant to comply with a request from the IIIrd Army to send troops to join them in order to march on the Capital. In addition, senior officers, as distinct from the younger ones, were opposed to marching on Constantinople. Moreover, the Albanians were sending a deputation to the Capital to see the real nature of occurrences as the CUP blocked the passage of Constantinople papers. ${ }^{65}$

Partly due to this 'misinformation', ${ }^{66}$ coupled with the signs of improvement in the situation from 17 April onwards ${ }^{67}$ together with Rifat Pasha's reassuring messages, Lowther seems to have misread internal occurrences, and took some unusual steps in endeavouring to disseminate 'the actual facts as widely as possible ...to calm the popular excitement' through British Consuls. ${ }^{68}$ His apprehension as to the Bulgarian attitude also made some effect on his action. ${ }^{69}$

Lowther first sent a telegraphic message to all consulates giving them his observations. He argued that the previous government had not been 
overthrown, but simply resigned 'in writing and with insistence', and the movement at the Capital was directed against 'ultra-liberal and antiMohammedan tendencies' of Hüseyin Hilmi Pasha's cabinet. Therefore, the Consuls should, 'judiciously and discreetly exercise' their influence in letting the truth be known. ${ }^{70}$ The following day, he went one step further and suggested, in an urgent telegram to the Consuls in Macedonia, that they 'should discreetly and unofficially suggest to malcontents to agree to send a small deputation to Constantinople to ensure themselves that the constitution is not in danger'. This step was taken in view of the impossibility for the population and officials in Macedonia to obtain impartial news as the CUP was holding back government telegrams. ${ }^{71}$

However, Lowther's intervention failed to produce the desired effect, as the Embassy was inundated with telegrams from Consuls throughout Macedonia, excepting Üsküb, all emphasizing the steadfastness of the IIIrd and IVth Army Corps, together with volunteers recruited by the CUP to march on the capital. ${ }^{72}$ Lowther then immediately withdrew his instructions and asked the Consuls to abstain from commenting on the situation with the authorities or others and let events take their own course. ${ }^{73}$

Lowther's request that some warships be despatched to Turkish waters to show some kind of interest in the future of the Ottoman Empire, and to send them where there was likely to be disturbances produced clashing views in the Foreign Office. While Sir Eyre Crowe, Senior Clerk and later Head of the Eastern Department, was prepared to inform the Admiralty accordingly, Mallet thought that it 'might look like intervention'. Given that the Turkish Charge d'Affaires had expressed to him a wish that there would be no outside interference, Mallet declined to support the proposal. He would only be prepared to comply with it if it would deter Bulgaria from moving, which, he thought, had now become a remote contingency. Grey intervened on Mallet's side because the presence of the British fleet would be 'variously interpreted as a demonstration against the CUP or against the Sultan ...', and so on. He would only run these risks if there were real danger to Britons' lives. ${ }^{74}$ Two days later, however, Grey decided to run these risks by sending some ships to Lemnos to await events there in order to protect British subjects as the likelihood of a clash between two opposing forces outside the Capital gathered momentum. ${ }^{75}$

On 17 April, Lowther decided to comply with Rifat Pasha's request apparently 'at the unanimous desire of the Cabinet' that Fitzmaurice accompany the Turkish delegation to reassure the Salonican troops that the Constitution was in no danger. The Ambassador was quite alive to the dangers that his action entailed, but the newly formed Ottoman cabinet stated that 'the present situation is so critical, not only from a Turkish but also from a European point of view, that this effort to save it should be 
made' ${ }^{76}$ However, when the Cabinet later decided to send the delegation without Fitzmaurice, Lowther was relieved. ${ }^{77}$

From 19 April onwards to the occupation of Constantinople on 24 April by Salonican troops, the Army of Operation (Hareket Ordusu), the Embassy merely monitored the situation and kept the Foreign Office informed. The attitude of the Embassy and the Foreign Office during the course of the counter-revolution was basically one of indifference. However, this is not to say that the Embassy was not critical of the CUP. On the contrary, Lowther's dislike for the CUP especially from the opening of the Parliament onward grew in intensity, and the parliamentary opposition came to seem to him to be a 'better' alternative. Yet, criticism of the CUP was never translated into active involvement in domestic politics, not least because of the awareness of unwanted consequences to which it would have led; but also due to the fact that Lowther was always conscious of the existence of what he called better elements within the CUP whose friendship he could not afford to lose. During the course of the counter-revolution, Lowther first became concerned about the Bulgarian attitude, and remained apprehensive about it until after the agreement had been signed on the 19th. Rifat Pasha's attitude does seem to have influenced his actions between 15th and 18th. ${ }^{78}$ On the other hand, it is safe to say that his disbelief that the CUP would unite such forces as it did against the capital, coupled with the information from the Consuls seeming to confirm his conviction had great effect on his decision to instruct the Consular Officers. But, as soon as he realized that the CUP was rallying around itself the Army as well as a large majority of people, he did withdraw the instructions. Even though his instructions can be interpreted as interference, one is inclined to the view that it was not tinged with any hostile intention because he quickly became, as will be seen, an admirer of the organization and ability of the CUP together with the Army of Operation.

Before moving on to Britain's policy after the suppression of the counter-revolution, it is now necessary to discuss allegations largely based on circumstantial evidence about British involvement. Private correspondence between the Embassy and the Foreign Office seem to cast grave doubts on the allegation, made by Ahmad, that the Levant Herald, a local paper published in English, and heavily involved in the vilification campaign of the CUP prior to the counter-revolution had strong links with the Embassy. ${ }^{79}$ If anything, the line taken by the paper previous to the counter-revolution caused the Embassy great dissatisfaction and even embarrassments, as it did not reflect the official policy.

What happened was that Dr Mizzi, the Editor, applied to Lowther for a subsidy of $£ 600$ a year to run the paper, which was then going down hill. The Porte had in a way assisted the paper under the old regime to the tune 
of $£ 600$ a year as an indemnification for the censorship to which it was subjected together with other papers. But the Young Turk revolution, which lifted the censorship, deprived the paper of this subsidy-like revenue. Though he said that he had been offered 'a considerable sum by the Russian Embassy to act as their Embassy organ' ${ }^{80}$ he was not certain whether or not to approach them. Passing on Dr Mizzi's request to the Foreign Office, Lowther at first seemed to be backing it, for otherwise the only English newspaper would have to fold up. ${ }^{81}$ But Hardinge was not enthusiastic about the scheme, as he put it:

We are opposed in principle to the idea of subventions to newspapers, and the only case that I know of where this has been done was that of an Egyptian newspaper, and it was decided two years ago to drop that subvention. ${ }^{82}$

By the time he received Hardinge's reply, Lowther had become better informed as to Mizzi. He now described Mizzi as 'so unbalanced that he would be a hopeless fellow to support'. The Ambassador was now in entire agreement with Hardinge. ${ }^{83} \mathrm{He}$ continued to complain severely of Mizzi to G. William Tyrrell, Senior Clerk and Private Secretary to Grey. ${ }^{84}$ In another private letter to Tyrrell, Lowther poured out his anger with 'busy-body' Mizzi, who was dragging his name 'into a squabble, he is having with the Committee paper, Tanin' ${ }^{85}$ In the meantime, Hardinge, now glad that Lowther had come to the same conclusion about Mizzi, wrote back to the Ambassador that Mizzi was 'a most unreliable man, and not at all straight. I know for an absolute fact that he has been, and still is drawing $£ 800$ a year from the Austrian Embassy, which is cashed quarterly through an Englishman in Constantinople, who goes to the Embassy to get the money .... ${ }^{86}$ In the light of all this, it seems difficult to maintain that the Levant Herald was financed, used or manipulated in any form by the British Embassy to discredit the CUP. ${ }^{87}$

According to Halide Edip Adıvar, Derviș Vahdeti, Editor of the Volkan, pivot of reactionary anti-CUP propaganda that played an important role in fomenting the counter-revolution "was thought to be the paid emissary of the British Embassy, a tool of Fitzmaurice', whose name, she maintains, was also implicated in the Incident of the 31 March. ${ }^{88}$ In similar fashion, Aubrey Herbert asserted that it was Fitzmaurice who dictated the anti-CUP oriented policy of the Embassy rather than Grey or Lowther. ${ }^{89}$ Chirol maintains that Lowther 'was disposed to back the wrong horse at the time of the counter-revolution'. Though Chirol was not sure to what extent the CUP's animosity after the counter-revolution against Lowther was justified, the latter being 'stolid and reserved' was unlikely to get on well with the 'more gushing members' of at the CUP. ${ }^{90}$ Sir Andrew Ryan, the Second 
Dragoman to the Embassy, bears out this description of Lowther, but does not support the charge brought against the Ambassador that 'he had fallen short of the great opportunity afforded by his first arrival in the glow of enthusiasm'. According to Ryan, 'the Young Turks were chauvinistic and no British diplomat was likely to make much headway against them'..$^{91}$

The fact that these allegations do not seem to coincide with the general picture drawn from archival material raises the question as to why the British might, supposing that they were indeed behind the counterrevolution, have been supporting it: presumably to bring Kamil back to power $^{92}$ with the Liberal Unions who were far more pro-British than the CUP. ${ }^{93}$ But bearing in mind the fact that Britain had, since the Young Turk revolution, wanted a strong Turkey with no formal attachment to herself as a barrier together with the Balkan States against Austro-German expansion in the Balkans as a result of Austria-Hungary's annexation of BosniaHerzegovina, it is worth asking what Britain could have gained from Kamil and the Liberal Unions being in power. It is clear that Britain was not in a position to go to the length of a formal alliance. Had she wanted an alliance or some kind of military convention to draw Turkey closer to herself, the CUP had already offered her all that.

The manner in which the counter-revolution was suppressed greatly impressed the Foreign Office: Grey was quick to congratulate the Turkish Chargé d'Affaires, Cevat Bey. ${ }^{94} \mathrm{He}$ similarly expressed himself to Lowther, stating that he was much impressed by the 'decision, purpose, discipline and strength' displayed by the leaders of the Army of Operation, and admitting that the CUP's real strength had been underrated. Although he continued to disapprove of the existence of an 'anonymous and irresponsible directing body', recent events had convinced him that 'the best elements' must be on the side of the CUP, for otherwise they would not have been successful. He concluded that Britain must back up these 'best elements', be more sympathetic and less critical of them. ${ }^{95}$ Hardinge took a similar line, warning Lowther that Fitzmaurice, an 'impressionable Irishman', must be made to adopt a friendly attitude towards the CUP. Specifically, Fitzmaurice

should be neither critical nor even impartial towards them [my italics]. He should try to show them that we are friendly and sympathetic, and wish to help them. That is our feeling here, and the only practical line of policy to follow. Our only hope for reformed Turkey rests now with the Young Turks. If they do not meet with sympathy and cannot lean on us, they will soon learn to lean on some other Power, and the splendid position we had at Constantinople a few months ago will be lost ...96

Lowther's initial response was to recommend caution. He reminded Grey

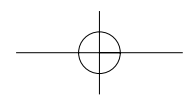


that the two leading Unionists, Talat and Bahaeddin Şakir, had assured him that they would go 'slowly' in the direction of reform and avoid offending the religious sentiments of the masses; but the subsequent events had not borne out this assurance. He also complained that since the suppression of the counter-revolution, the CUP had adopted a policy exterminating all that savoured of opposition. He warned that the country was 'in a disturbed condition underneath', and added that there seemed little chance of a military dictatorship, though in his opinion such was probably the best solution. He also noted that the CUP leaders were apt to overlook 'the existence of Asia Minor and base their ideas on Turkey, consisting only of the Macedonian provinces'. Yet he was prepared to be more sympathetic to the CUP, and expressed the hope that it would now come to the fore, obviating the need to contact it behind the back of a legal government, usually opposing it. He also welcomed the likely appointment of Ferid Pasha as Grand Vizier, despite his pro-German reputation, seeing in him a 'strong man' able to grapple with the situation. ${ }^{97}$

Lowther's reply to Hardinge did emphasize the difficulty he had hitherto faced in his dealings with the CUP:

with every minister since the Constitution, I have been on the best of terms, but unfortunately those ministers have, after a few days or weeks, rarely been able to retain the favour of the violent members of the Committee. My aim throughout has been that the Embassy should be in complete harmony with the government in power and with the moderates, and I believe, best members of the Committee. ${ }^{98}$

Lowther grew less cautious once he realized that the deposition of Abdülhamid was not likely to cause fresh disturbances throughout the Empire. He argued that it was high time for the CUP to assume positions and responsibility, and regretted Mahmud Şevket Pasha's advice to the CUP not to take office. ${ }^{99}$ That said, a meeting with Mahmud Şevket Pasha, Commander of the Army of Operation, made an excellent impression on him:

He has no doubt a great work before him, but he seemed determined to carry it through, and if his actions in any way correspond with his declarations, which seemed to me to be sincere. I cannot but think that the choice that has been made of Mahmud Şevket Pasha is an excellent one ... ${ }^{100}$

But late May 1909, there were rumours of serious differences between Mahmud Şevket Pasha and the CUP, and at a meeting with Lowther, Mahmud Şevket Pasha openly deprecated the activities of 'a body of irresponsible and inexperienced young men styling themselves the 
Committee of Union and Progress, who thwarted as much as they assisted the government'. ${ }^{101}$ At the Foreign Office, Mallet did not find this development 'reassuring for stable government'; ${ }^{102}$ but he still asserted that, but for the CUP's success, reactionaries would have massacred Christians everywhere, as they had done in Adana during the counter-revolution ${ }^{103}$ For his part, Hardinge reiterated his belief that a military despotism, presumably under Mahmud Şevket Pasha, would be the best safeguard of the constitutional regime. ${ }^{104}$

In the meantime, in order to establish direct contacts with the CUP, T.B. Hohler, the First Secretary to the Embassy, was instructed to see Cavid Bey, an influential figure of the inner circle of the CUP, who was very likely to come to the fore as a financial expert. Hohler pointed out to him that Britain's policy was to help set up a stable government and a reformed administration in Turkey, and that this policy was being pursued regardless of who was in power. In answer to Cavid Bey's complaint that the British Embassy had refrained from making direct contact with the CUP as opposed to other embassies, Hohler emphasized the fact that

It had been impossible to know who did represent the real governing force of the country, for from ministers and valis down, all authority was subjected to the irresponsible interference of the Committee, whose chief was not even known to the members themselves, and who apparently varied from time to time.

In view of the fact that there was so much dissent rather than unity within the CUP, it was, Hohler pointed out, impossible for the Embassy to know who was the right person or group to approach. He then urged upon Cavid Bey the advisability of the CUP taking responsible office and coming to the fore. The latter suggested in return that the CUP members be employed under ministers as Müsteșar like parliamentary under-secretaries in Britain through whom official contact might be made. ${ }^{105}$

While tightening up his links with the CUP, Lowther gave a cold shoulder to Kamil and Nazım Pashas, who came to the Embassy to pour out their grievances as regards internal politics. But, Lowther did not attach much importance to the gloomy picture they had drawn. For one thing, Kamil's foreboding might be accounted for by his natural disappointment at the victory of his political rival, Ferid Pasha, as an outward ally of the CUP. For another, they had been hardly in touch with anybody other than their own supporters. ${ }^{106}$ Lowther's 'ill-treatment' caused Kamil to write directly to Grey asking for protection. He suggested that Lowther be instructed, if possible together with his French and Russian colleagues, to do what he could to neutralize the German influence at Constantinople. Though the Foreign Office acknowledged his letter promising him protection of the sort 
that he had been given in the past, his suggestion as to Lowther's dealings was politely ignored, while his conduct of affairs during the Bosnian Crisis was flattered. ${ }^{107}$

İsmail Kemal, an ally of Kamil Pasha during the counter-revolution, was to receive his share of this 'cold' attitude later in the autumn of 1909, when he went to see Grey in the Foreign Office in London, but was received instead by Tyrrell, Grey's Private Secretary. The latter simply told him that his criticism of the CUP for having replaced Abdülhamid's secret camarilla did not seem to hold water any longer as there was a certain inclination on the part of the CUP to take office and responsibility. In addition, it was high time, Tyrell pointed out to him that they all dropped incrimination against each other and put their heads together for the regeneration of the country. ${ }^{108}$

As could be expected, under these circumstances, Cavid's appointment as Finance Minister delighted the Foreign Office. Lowther, described him as 'intelligent, an exceptionally good orator, and debater, genial, liberal minded'. ${ }^{109}$

With the Turkish decision to invite German General von der Goltz to reorganize the Turkish Army, Britain's sincerity in desiring a strong Ottoman Empire was put to the test. It first aroused fears in the Foreign Office. While Alwyn Parker found the whole dispatch 'unpleasant', Mallet expressed his concern that the Turkish Army would 'become more and more imbued with German ideas and, having forged the weapon, the Germans are likely to use it in a general conflagration'. It then fell to Hardinge to make Britain's line clear: 'We may not like the Germanizing of the Turkish Army, but it is to our advantage that Turkey should be strong, and we can hardly blame the Turks for turning to a German General who has already done wonders to their army.' Grey was more explicit in determining the line of the policy and its limits: 'It remains to be seen whether the new regime will be strong enough to use German help, and retain its own policy, which should be a good understanding with Russia and Bulgaria as the counterpoise to German pressure.' ${ }^{110}$

A month later, when the clouds of war gathered over the Balkans between Turkey and Greece this time over Crete, with Bulgaria waiting to take advantage, Parker now seemed glad that the Turkish army, under the training of von der Goltz, would steadily become more and more powerful, deterring Bulgaria from moving to realize her aspirations in Macedonia. ${ }^{111}$

There is no doubt that with the advent of the Young Turks revolution AngloTurkish relations took a sharp turn for the better. The revolution in itself constituted a radical change in the political status quo of the Balkans and of the Near East, introducing a new dimension to the considerations in terms 
of balance of power within the concept of European systems of alliances. It was regarded as a severe blow to German prestige, and very much like a seesaw, British influence gained ascendancy. The British responded swiftly to this welcomed development, first clearing up all the obstacles that they themselves had put in front of the previous regime, for example, the suspension of the Anglo-Russian scheme for a mobile force, and the agreement as to the future withdrawal of Macedonian gendarmerie officers and so forth, thus giving the newly born regime a politically vital breathing space. ${ }^{112}$

Some of the myths that have gathered around the Anglo-Russian understanding of 1907, leading to explanations to what is sometimes seen as British reluctance to prop up the Anglophile Young Turk regime are not always fully supported by primary sources. This is not to say, however, that Russia was disregarded as a power factor. What seems to have been the case, as far as the British were concerned, was that they recognized, from the outset, the slightly different effect that Russia as an ally and Turkey as a friend would have upon Britain's policy. In other words, Russia and the Ottoman Empire had, as it were, different functions in British policymaking. From the British standpoint, Turkey was not a European Great Power, though the Foreign Office seemed to have believed in the possibility of what it called a strong and regenerated Turkey. ${ }^{113}$

The Empire, however, did occupy an important place in British strategical planning in connection with the balance of power in the Balkans. When the Young Turks emerged with Anglophile leanings, it did not lead the British to give up Russia; nor did it mean giving a cold-shoulder to the new regime. In essence, there was no need to do so, as the relations with the two countries did not present any inconsistency. In broader terms, Britain needed the two at different levels and in different forms and for different purposes. What was, of course, anathema to the Foreign Office, as was recognized at the early stages of the revolution, was the option of supporting Turkey as a barrier against Russia. Given that Russia had long ceased to be an expansionist power in the Balkans, particularly since the Russian defeat of 1904-5 at the hands of the Japanese, but that Austria appeared to be at the zenith of her strength following her annexation of Bosnia-Herzegovina, the British did not seem to have miscalculated the international political arena. ${ }^{114}$

The British attitude towards Turkish domestic politics was, to a great extent, influenced by their strategical considerations. Bearing in mind the fact that a strong Turkey could only be created by a stable government, the British did not attach much importance to the question of who was in power. It is obvious that the CUP's co-operative attitude was much appreciated. In the ensuing power struggle after the Young Turk revolution, the Embassy steered clear of any action likely to be interpreted as interference. Once the 
CUP was seen to be acting as a destabilizing factor, then came British criticism mostly kept to private correspondence. Yet this is not to say that the Embassy did not cold-shoulder the CUP. At this stage, the CUP's nationalistic and chauvinistic tendencies were regarded by the Foreign Office as the beginning of the dismemberment of the Empire, something that the British did not wish to see happening. The Embassy thought that any alternative to the CUP might be better. But as soon as they realized, after the suppression of the counter-revolution, that the CUP was hand in glove with the army, and had popular support, they turned back to it.

It could be maintained that British policy was more influenced by Turkish attitude towards Britain than other factors, as it was to become obvious in 1910-11. It was, after all, the CUP, and the Army in general who underestimated British friendship and assistance, ${ }^{115}$ digging their own graves and preparing their own political isolation, which would be severely felt by Turkey during the Tripoli and Balkan Wars.

\section{NOTES}

1. F. Ahmad, 'Great Britain's Relations with the Young Turks, 1908-1914', Middle Eastern Studies (1966), pp.310-16; F. Ahmad, 'The Late Ottoman Empire', in M. Kent, The Great Powers and the End of the Ottoman Empire (London, 1984), pp.13-17. See, B. Samardziev, 'British Policy towards the Young Turk Revolution, 1908-1914 (Some Problems)', Bulgarian Historical Review, 3 (1983), pp.22-43. See also S. Akșin, 31 Mart Olayl (Istanbul, 1972), pp.290-1.

2. Ibid.

3. Akșin, 31 Mart Olayl, p.356.

4. Fitzmaurice to Tyrrell, 25 Aug. 1908, Pte. Grey Papers (FO800/79)

5. Chirol to H.W. Steed, 6 Dec. 1908, Pte. Chirol Papers (The Times Archives, London); Chirol to Tyrrell, 19 Nov. 1909, Grey Papers (FO800/16).

6. Lowther to Grey, 4 Aug. 1908, Pte. Lowther Papers (FO800/193B); Grey Papers (FO800/79).

7. Lowther to Grey, 11 Aug. 1908 and 25 Aug. 1908, Pte. Lowther Papers (FO800/193B); Grey Papers (FO800/79).

8. Lowther to Grey, 11 Aug. 1908, 25 Aug. 1908 and 31 Aug. 1908, Pte. Lowther Papers (FO800/193B); Grey Papers (FO800/79).

9. Lowther to Grey, 2 Sept.1908, FO371/6559, 31787.

10. Lowther to Grey, 12 Oct. 1908, FO371/559, 31787.

11. See, for the arrangement of the meeting, FO371/545, 28993; FO371/548, 32132.

12. For Ottoman Policy during the Bosnian International Crisis, see H. Ünal, 'Ottoman Policy during the Bosnian Annexation Crisis, 1908-1909' (unpublished Ph.D. thesis, University of Manchester, 1992). See, also 'Ottoman Policy during the Bulgarian Independence Crisis: Ottoman-Bulgarian Relations at the Outset of the Young Turk Revolution', Middle Eastern Studies, Vol.34, No.4 (Oct. 1998), pp.135-76.

13. Grey to Lowther, 13 Nov. 1908, Pte. Grey Papers (FO800/79); Lowther Papers (FO800/193A).

14. Hardinge to Lowther, 17 Nov. 1908, Pte. Lowther Papers (FO800/193A); Hardinge to Block, 17 Nov. 1908, Pte. Hardinge Papers 13.

15. Lowther to Grey, 14 Sept.1908, Pte. Lowther Papers (FO800/193B); Grey Papers 
(FO800/79).

16. Lowther to Grey, 27 Oct. 1908, Pte. Lowther Papers (FO800/193B); Grey Papers (FO800/79).

17. Lowther to Grey, 27 Oct. 1908, Pte. Lowther Papers (FO800/193B); Grey Papers (FO800/79); See for rumours about dethronement, Grey to Lowther, 30 Oct. 1908, Private telegram, Grey Papers (FO800/79); Lowther to Grey, 3 Nov. 1908, Pte. Lowther Papers (FO800/193B)

18. Grey to Asquith, 11 Sept.1908, Pte. Grey Papers (FO800/79).

19. Grey's minute, FO371/559, 31787.

20. Lowther to Grey, 31 Aug. 1908, Pte. Lowther Papers (FO800/193B); Grey Papers (FO800/79); Lowther to Hardinge, 20 Dec. 1908, Pte. Lowther Papers (FO800/193B).

21. Lowther to Hardinge, 20 Dec. 1908, Pte. Lowther Papers (FO800/193B).

22. Akșin, 31 Mart Olayl, p.31.

23. Lowther to Grey, 31 Oct. 1908, FO371/553, 36562, and minutes; FO371/554, 37658.

24. Lowther to Grey, 27 Oct. 1908, Pte. Lowther Papers (FO800/193B); Grey Papers (FO800/79).

25. Hardinge to Lowther, 17 Nov. 1908, Pte. Lowther Papers (FO800/193A).

26. Lowther to Grey, 20 Dec. 1908, FO800/546, 45084.

27. Ibid. Mallet's minute.

28. Grey to Lowther, 15 Dec. 1908, FO371/558, 43816.

29. Lowther to Hardinge, 8 Dec. 1908 and 22 Dec. 1908, Pte. Lowther Papers (FO800/193B).

30. Lowther to Montgomery, 2 Sept.1908, Private Telegram; Grey to Lowther, 9 Sept. 1908, Pte. Grey Papers (FO800/79). See for further details S. Akșin, Yüz Soruda İttihat ve Terakki ve Jön Türklük (Istanbul, 1972) p.46; P. P. Graves, Briton and Turk (London, 1941), pp.107-8.

31. A minute by a Foreign Office official is a very striking example of this line: 'it is to be hoped that Kiamil will get his vote of confidence if Ahmed Riza is the alternative' (FO371/546, 43987).

32. Lowther to Grey, 29 Dec. 1908, Pte. Lowther Papers (FO800/193B); Grey Papers (FO800/79).

33. Grey to Lowther, 27 Nov. 1908, Pte. Lowther Papers (FO800/193A); Grey Papers (FO800/79).

34. Lowther to Hardinge, 22 Dec. 1908, Pte. Lowther Papers (FO800/193B).

35. FO371/546, 43987; Hardinge to Lowther, 29 Dec. 1908, Pte. Lowther Papers (FO800/193A).

36. Lowther to Hardinge, 6 Jan. 1909, Pte. Lowther Papers (FO800/193B).

37. Lowther does not seem to have been pleased with Kamil's proceeding (Lowther to Grey, 12 Feb. 1909 and 14 Feb. 1909, FO371/760, 5723, 5828).

38. Akșin, Ittihat ve Terakki, pp.33-8.

39. Lowther to Grey, 15 Feb. 1909, FO371/760; Grey to Lowther, 17 Feb 1909, FO371/761.

40. Lowther to Hardinge, 16 Feb. 1909, Pte. Lowther Papers (FO800/193B).

41. Hardinge to Lowther, 22 Feb. 1909, Pte. Lowther Papers (FO800/193A); Hardinge's minute on Lowther to Grey, 22 Feb. 1909, FO371/768, 7056.

42. Grey to Lowther, 17 Feb. 1909, FO371/761,7180,7179; Hardinge to Lowther, 23 Feb. 1909, Pte. Lowther Papers (FO800/193A).

43. Lowther to Grey, 8 Feb, 1909, Pte. Lowther Papers (FO800/193B); Grey Papers (FO800/79).

44. Lowther to Hardinge, 16 Feb. 1909; Lowther to Gorst, 26 Feb. 1909, Pte. Lowther Papers (FO800/193B).

45. Lowther to Hardinge, 2 March 1909, Pte. Lowther Papers (FO800/193B).

46. Lowther to Grey, 16 March 1909, Pte. Lowther Papers (FO800/193B); Grey Papers (FO800/79).

47. Lowther to Hardinge, 2 March 1909, 10 March 1909, 24 March 1909 and 31 March 1909, Pte. Lowther Papers (FO800/193B); Grey Papers (FO800/192).

48. Colonel Surtees stated that 'the general state of discipline in the officer ranks is decidedly a danger and unless authorities take up the question strongly and absolutely forbid all military interference in politics, it will not be surprising if we find ourselves sliding into a military 
revolution' (Surtees to Lowther, 27 Feb. 1909, FO195/2323). See also Lowther to Grey, 14 April 1909, FO371/770, 14544; FO421/250; Cabinet Papers (CAB37/99, no. 62).

49. Lowther to Grey, 13 April 1909, FO371/770, 13941; FO421/250.

50. Lowther to Grey, 13 April 1909, FO371/770,13942, and minutes; FO421/250.

51. Lowther to Grey, 14 April 1909, FO371/770, 14033, 14035, 14049.

52. Ibid. and minutes. The correspondent of The Times, P.P. Graves, was watching events closely in the streets of Constantinople (Graves, Briton and Turk, pp.127-9).

53. Interestingly, the news about the overthrow of the CUP produced a shocking effect among Armenian circles abroad, which still considered the CUP 'friendly' to their interests (Friends of Armenia to the Foreign Office, 14 April 1909, FO371/770, 14186).

54. Lowther to Grey, 14 April 1909, Cabinet Papers (CAB/37/99, no. 62.)

55. Lowther to Hardinge, 14 April 1909, Pte. Lowther Papers (FO800/193B).

56. Surtees to Lowther, 14 April 1909, FO195/2323.

57. See for Grey's congratulations to him, 15 April 1909, Private Telegram, prepared by Mallet, Grey Papers (FO800/79).

58. Lowther to Grey, 15 April 1909, FO371/770,14172,14182.

59. Grey to Lowther, 15 April 1909, FO371/770,14182.

60. Lowther to Lamb, 15 April 1909, FO195/2330.

61. Lamb to Lowther, 15 April 1909, FO195/2328.

62. Lowther to Grey, 16 April 1909, FO371/770,14223.

63. Ibid., minutes.

64. Sampson to Lowther, 15 April 1909 and 16 April 1909, FO195/2304.

65. Satow to Lowther, 16 April 1909, FO195/2328.

66. Though the Consular Officer's first impression turned out to be baseless (Sampson to Lowther, 17 April 1909, received on 18 April 1909, FO195/2304), the Albanians' defiant attitude remained unchanged throughout. See reports and telegrams from Satow to Lowther, 16 April 1909, 19 April 1909, 20 April 1909, 21 April 1909 and 23 April 1909, FO195/2328.

67. See for instance, Surtees to Lowther, 17 April 1909, FO195/2323.

68. Lowther to Grey, 20 April 1909, FO371/770,15582; FO421/250; Cabinet Papers (CAB37/99, no. 64.) İsmail Kemal alleges that it was him who instigated Lowther to instruct the Consuls (İsmail Kemal, Memoirs of İsmail Kemal Bey (London, 1920), p.343. Ahmad and Akșin treat this together with some other circumstantial evidence as proving that the British Embassy was behind the counter-revolution (Ahmad, 'Great Britain's Relations', p.314; Akșin, 31 Mart, pp.138-9). This view is not borne out by British documents. Obviously, Lowther as Ambassador was responsible for providing his Consuls with information and even occasionally argument. In fact, before Lowther instructed them, some Consuls had already asked the Embassy for information and argument (see for example, Grey to Lowther, 16 April 1909, FO195/2328, "Vali himself at head of Monastir Committee represents Constantinople movement as reactionary. Is it liberal ...?'). On the other hand, it seems arguable whether Lowther had much confidence in İsmail Kemal. In writing to Hardinge he said: 'İsmail Kemal has bolted of which I am glad, as I do not trust him'. On 20 April, Lowther did not like the presence of Kamil Pasha in the Embassy, and 'got rid of him', hoping that the ex-Grand Vizier would not return. See Lowther to Hardinge, 20 April 1909, Pte. Lowther Papers (FO800/193B).

69. It is interesting to note that at this juncture the Foreign Office did not encourage the Serbian attempt to arrive at an understanding with Bulgaria ostensibly against any Austrian move (Grouitch to the Foreign Office, 15 April 1909 and Grey to Whitehead, 15 April 1909, FO371/770, 14122).

70. Lowther to Consuls, 16 April 1909, FO195/2330, 2314.

71. Lowther to Consuls, 17 April 1909, FO195/2330.

72. Sampson (Adrianople) to Lowther, 17 April 1909, received on 18 April 1909, FO195/2304; Lamb (Salonica) to Lowther, 16 April 1909, 17 April 1909, 18 April 1909, 19 April 1909 and 20 April 1909, FO195/2328; Greig (Serez) to Lowther, 17 April 1909, 18 April 1909, 19 April 1909 and 20 April 1909, FO195/2328; Geary (Monastir) to Lowther, 17 April 1909 and 
18 April 1909, FO195/2328.

73. Lowther to Geary and others (Salonica, Serez, Üsküb, Adrianople), 19 April 1909, FO195/2330.

74. Ibid. and minutes. But Grey did not hesitate to send ships to Mersin consequent on widespread disturbances at Adana and in its vicinity (Lowther to Grey, Grey to Lowther, 17 April 1909, FO421/250).

75. Grey to Lowther, 19 April 1909, FO371/770,14560.

76. Lowther to Grey, 17 April 1909, FO371/770,14474.

77. Lowther to Grey, 17 April 1909, received on 18 April 1909, FO371/770, 14476; FO421/250; Akșin, 31 Mart, p.172.

78. See for instances Rifat Pasha's assurances as regards the internal developments, FO371/770, 14730 .

79. In actual fact, Ahmad seems to maintain that the paper was purchased or subsidised by the Embassy (Ahmad, 'Great Britain's Relations', p.313).

80. Lowther on several occasions talked of Russian agents, stirring up trouble in Constantinople before the counter-revolution: 'there are many Russian agents here, probably with a view to stirring up strife ... there are many indications that she (Russia) does not want the new regime to thrive, and any trouble, dynastic or other would be welcome'. See, Lowther to Grey, 8 Feb 1909, Pte. Lowther Papers (FO800/193B); Grey Papers (FO800/79). On 16 February, he wrote again in a similar strain, adding that 'Zinoviev' (The Russian Ambassador at Constantinople) confines himself to saying that a reformed Turkey is an impossibility, but that his staff are very much active especially in Committee circles. See, Lowther to Hardinge, 16 Feb. 1909, Pte. Lowther Papers (FO800/193B); Hardinge Papers (FO800/192). On 16 March he further reported that 'the action of the Russian Embassy is rather curious. One of the staff is always in the lobbies, influencing the members strongly in support of the Committee ...'. See Lowther to Grey, 16 March 1909, Pte. Lowther Papers (FO800/193B); Grey Papers (FO800/79). Tevfik Pasha intimated to Lowther that Sultan Abdülhamid believed that the money distributed to mutinous soldiery was probably sent from Russia. See Lowther to Grey, 5 May 1909, FO371/772, 17613. But after the suppression of the counterrevolution, Lowther professed to disbelieve that Russia had been fomenting it, though he remained suspicious of the Russian Ambassador, who was not 'easy to fathom, and contents himself with saying that Constitutional government is an impossibility in Turkey'. See Lowther to Grey, 5 May 1909, Pte. Lowther Papers (FO800/193B); Grey Papers (FO800/79).

81. Lowther to Grey, 26 Feb. 1909, Pte. Lowther Papers (FO800/193B).

82. Hardinge to Lowther, 23 March 1909, Pte. Lowther Papers (FO800/193B).

83. Lowther to Hardinge, 31 March 1909, Pte. Lowther Papers (FO800/193B); Hardinge Papers (FO800/192).

84. Lowther to Tyrrell, 18 March 1909, Pte. Lowther Papers (FO800/193B); Grey Papers (FO800/ 79).

85. Lowther to Tyrrell, 25 March 1909, Pte. Lowther Papers (FO800/193B); Grey Papers (FO800/79).

86. Hardinge to Lowther, 6 April 1909, Pte. Lowther Papers (FO800/193A).

87. Cf. Ahmad, 'Great Britain's Relations', p.313; Block to Hardinge, 12 May 1909, Pte. Hardinge Papers (FO800/192). Though Ahmad apparently consulted Lowther, Hardinge and Grey Papers, he does not mention these letters.

88. Halide Edip, Memoirs of Halide Edip (London, 1926), p.278; Cf. Ahmad, 'Great Britain's Relations', p.312 and Lowther to Grey, 6 April 1909, FO371/770,13687.

89. A. Herbert, Ben Kendim: A Record of Eastern Travel (London, 1923) edited by Desmond McCarty, pp.268-71; M. Fitzherbert, The Man who was Greenmantle: A Biography of Aubrey Herbert (London, 1983), pp.82-3. Aubrey Herbert Papers deposited to the Somerset Record Office in Britain are not very articulate as to why he blames Fitzmaurice for having alienated the CUP.

90. Chirol to Steed, 01 Sept.1909, Pte. Chirol Papers.

91. A. Ryan, The Last of the Dragomans (London, 1951), p.71. In addition, Ryan, in his letters 
jotted down during the counter-revolution, does not give any indication whatsoever as to the culpability of any British personnel at the Embassy (ibid., pp.59-61); Cf. Ahmad, 'Great Britain's Relations', p.310. Ahmad also seems inclined to the view that Fitzmaurice and other British officials, particularly Major G.E. Tyrrell, Military Attache, were implicated in the assassination of Mahmud Șevket Pașa in 1913 (ibid., pp.313-14); Cf. G. W. Swanson, 'Mahmud Șevket Pașa and the Defence of the Ottoman Empire: A Study of War and Revolution During the Young Turk Period' (unpublished Ph.D. thesis, 1970, Indiana University, History, Modern).

92. Ahmad, 'Great Britain's Relations', p.314.

93. Akșin, 31 Mart, pp.349-60.

94. Grey to Lowther, 29 April 1909, FO371/71,16324.

95. Grey to Lowther, 30 April 1909, Pte. Grey Papers (FO800/79); Lowther Papers (FO800/193A).

96. Grey to Lowther, 1 May 1909, Pte. Lowther Papers (FO800/193A).

97. Lowther to Grey, 5 May 1909 and 12 May 1909, Pte. Grey Papers (FO800/79); Lowther Papers (FO800/193B). In fact, Lowther had always been in touch with the moderate members of the CUP. Lowther to Grey, 5 May 1909, FO371/771, 17613. In his letter to Tyrrell, dated 27 June, Fitzmaurice also complained that the CUP went too fast in their endeavour to reform, which then shook up 'the very natural religious and other prejudices' of Moslem masses. But he was sure that the Embassy had given them wise counsel. See, Fitzmaurice to Tyrrell, 27 June 1909, Pte. GP (FO800/79).

98. Lowther to Hardinge, 12 May 1909, Pte. Hardinge Papers (FO800/192); Lowther Papers (FO800/193B).

99. Lowther to Grey, 5 May 1909, FO371/771, 17605.

100. Lowther to Grey, 5 May 1909, FO371/771, 17613.

101. Lowther to Grey, 21 May 1909, FO371/776, 20279.

102. Lowther to Grey, 21 May 1909, FO371/776, 20294, Mallet's minute.

103. Lowther to Grey, 25 May 1909, FO371/772, 20294, Mallet's minute.

104. Lowther to Grey, 21 May 1909, FO371/776, 20279, Hardinge's minute.

105. Lowther to Grey, 26 May 1909, FO371/772, 20299.

106. Lowther to Grey, 10 June 1909, FO371/776, 23047. Apparently Lowther had not seen them since 24 April.

107. Grey to Kamil Pașa, 28 June 1909, Pte. Grey Papers (FO800/79); Hardinge to Grey, 12 May 1909, Private Memorandum, Grey Papers (FO800/92). Lowther later did his utmost to discourage the ex-Grand Vizier from forming a cabinet with the CUP lest he again ends up in the same messy position with the Committee. See Lowther to Grey, 20 July 1909, Pte. Lowther Papers (FO800/193B); Grey Papers (FO800/79).

108. Tyrrell to Grey, 21 Oct. 1909, Private Memorandum, Grey Papers (FO800/79).

109. Lowther to Grey, 28 June 1909, FO371/777,25167, and minutes.

110. Goschen to Grey with observations from the Military Attache at Berlin, Colonel T. Trench, 21 June 1909, FO371/775,23001, and minutes. The Germans did set great store by Goltz's employment in the Turkish Army. See, F.B. Schulte, Vor Dem Kriegsausbruch, Deutschland, die Turkei und der Balkan (Düsseldorf, 1980), pp.19, 21-2.

111. Parker's minute on Cartwright to Grey, 28 July 1909, FO371/779,28765.

112. For details of the annexation crisis and Britain's policy see Hasan Ünal, 'British Policy Towards the Ottoman Empire During the International Crisis: Bulgaria's Declaration of Independence and the Annexation of Bosnia and Herzegovina by Austria-Hungary, 1908-1909', Bulgarian Historical Review (Jan. 2001).

113. Ibid.

114. Ibid.

115. Colonel Surtees went to see, on Lowther's instruction, senior officers in the War Ministry, particularly Lieutenant General Pertev Pasha, Chief of the Staff to Mahmud Sievket Pasha, to put out feelers to find out political inclinations of the Army in general. The General declared that all senior officers, including himself were members of the 
CUP, and made no secret of their Germanophile leanings. Throughout the conversation, Pertev Pasha seemed to have questioned the real value of British friendship, especially from a military point of view (Surtees to Lowther, 14 May 1909, FO195/2323;

FO371/1776, 19419).

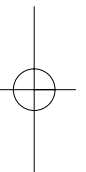

